\title{
Análise de Ex 3,7-15 em perspectiva narrativa
}

\author{
Analysis of Ex 3,7-15 in narrative perspective
}

Leonardo Agostini Fernandes

\section{Resumo}

Ex 3,7-15 é a segunda cena da experiência mosaica no Horeb (Ex 3,14,18). Como Moisés adentrou no deserto, com o rebanho do seu sogro, YHWH, em sua teofania, adentrou e inflamou o íntimo do genro de Jetro para mostrar, pela vocação e missão, o sentido e o valor do seu aprendizado como pastor. Sob esta ótica, a presente reflexão objetiva propor uma interpretação de Ex 3,7-15 em chave narrativa. Após a introdução, a reflexão é desenvolvida a partir de três tópicos: 1) Texto segmentado e notas de crítica textual; 2) Delimitação e estrutura da seção; 3) Análise das subseções; encerrando-se com algumas considerações finais. Quanto à metodologia, abordagens diacrônicas e sincrônicas foram conjugadas, visando a melhor compreensão do texto. Ter sido encontrado por YHWH, deserto adentro, tornou-se um marco que revigorou em Moisés a força do altruísmo e da alteridade em relação ao seu povo sofrido sob a opressão do Egito.

Palavras-chave: Diálogo. Vocação. Missão. Teofania. Livro de Êxodo.

\section{Abstract}

Ex 3,7-15 is the second scene of the Mosaic experience in Horeb (Ex 3,1-4,18). As Moses entered the desert, with his father-in-law's herd, YHWH, in his theophany, he entered and inflamed the intimate of Jethro's son-in-law to show the meaning and value of his learning as a shepherd through his vocation and mission. In this perspective, the present reflection aims to propose an interpretation of Ex 3,7-15 in a narrative key. After the introduction, the 
reflection is developed on three topics: 1) Segmented text and textual criticism notes; 2) Delimitation and structure of the section; 3) Analysis of the subsections; ending with some final considerations. As for the methodology, diachronic and synchronic approaches were combined, aiming at a better understanding of the text. Having been found by YHWH, in the desert, became a landmark that reinvigorated in Moses the strength of altruism and empathy in relation to his people who suffered under the oppression of the Egypt.

Keywords: Dialogue. Vocation. Mission. Theophany. Book of Exodus.

\section{Introdução}

Ex 3,1-6 apresenta o impacto que ocorreu na vida de Moisés no momento em que se encontrou diante da divindade no monte Horeb. ${ }^{1}$ Essa experiência deu início e desencadeou a reviravolta na vida e nos planos de Moisés. Os desdobramentos desse encontro são narrados na sequência (Ex 3,7-4,18).

Moisés fugira do Egito para salvar sua vida das mãos do Faraó, mas o "Egito não fugiu" do íntimo de Moisés e tampouco a lembrança a respeito da sorte do seu povo o deixou. Visto que o rei do Egito está morto (Ex 2,23; 4,19), uma nova etapa tem início e, por iniciativa e vontade divina, Moisés foi chamado a regressar ao Egito, a fim de realizar uma missão libertadora.

$\mathrm{O}$ ouvinte-leitor se depara com uma intenção divina inusitada, pois Ex 2,11-15, de forma antecipada, descrevera as incapacidades de Moisés tanto diante do egípcio, como diante dos seus irmãos de raça. Ao lado disso e na sequência narrativa, Ex 2,16-22 descreve que a fuga proporcionou a Moisés, em Madiã, um êxito pessoal que não tivera no Egito. A vida de Moisés, refeita e estabilizada com "casa, mulher e filhos", sofreu um duro golpe, porque o chamado e a missão reacenderam, nele, o ímpeto libertador e executor da justiça.

YHWH, assumindo a fala, revelou para Moisés o seu interesse pela situação do seu povo que sofria no Egito. Ex 3,7.9 retoma as informações iniciais do livro de Exxodo a respeito da mudança da sorte dos descendentes de

\footnotetext{
${ }^{1}$ Procurou-se, dentro do possível, seguir a lógica do texto, e se fez uso tanto de YHWH como 'Elōhîm, visto que Ex 3,1-4,18 foi elaborado, provavelmente, a partir da fusão de tradições: yahwista e 'elohista (CHILDS, B. S., El Libro del Éxodo, p. 87-89; HOUTMAN, C., Exodus, p. 91-102; PRIOTTO, M., Esodo, p. 29-37).
} 
Jacó (Ex 1,8-22). Há uma distância temporal que deve ser admitida entre as condições nas quais nasceu Moisés e a inédita experiência no monte Horeb. Apesar disso, a narrativa deixa claro que o 'Elōhîm que vê a opressão e escuta o grito do povo é YHWH, manifestado no fenômeno da sarça e se faz presente na vida de Moisés, apresentando-lhe as suas intenções.

Então, de imediato, surgem algumas questões: Pelas notícias narradas, o grito dos filhos de Israel foi o elemento que desencadeou a decisão da intervenção divina? Mas, esse grito já não tinha acontecido há tanto tempo? Deus se fizera "surdo" a esse grito? Por que Deus deixou transcorrer cerca de quarenta anos para se fazer presente na vida de Moisés a fim de chamá-lo para uma missão libertadora no momento em que o eleito já estava com quase oitenta anos de idade?

A fala divina não justifica esse "grande lapso temporal", mas coloca diante de Moisés a decisão de intervir a partir do clamor dos filhos de Israel após a notícia da morte do rei do Egito (Ex 2,23-25). Este rei não é citado por nome e tampouco é denominado pelo título de Faraó. Seria possível cogitar de que se tratasse do mesmo que tomara as medidas para conter o crescimento demográfico dos filhos de Israel (Ex 1,8-14), decretando o extermínio dos meninos (Ex 1,15-22)? ${ }^{2}$

Um dado curioso: já que morreu o rei opressor dos filhos de Israel no Egito, era de se esperar que, com a mudança na condução do governo, que certamente aconteceu, terminasse o regime opressor; mas, não houve mudança. Ao lado disso, não é retomada a notícia sobre a filha do Faraó que se tornara a mãe adotiva de Moisés. O ouvinte-leitor pode, igualmente, admitir a sua morte.

As intenções de YHWH são reveladas a Moisés, que se torna a resposta divina aos apelos do povo, em uma tríplice direção temporal. Nesse sentido, Ex 3,7-15 recupera fatos (passado), atualiza situações (presente) e preconiza os projetos de YHWH para o bem do seu povo (futuro). Sem entrar nos detalhes, o projeto, que se iniciou na apresentação divina feita a Moisés, encontrou um primeiro êxito com a morte dos primogênitos (Ex 12,29-34), ocasionando o êxodo do Egito, mas o desfecho final aconteceu com a eliminação e morte dos

\footnotetext{
${ }^{2}$ Ex 1,11 parece refletir um dado histórico. As cidades de Pitom e de Ramsés, segundo a narrativa, foram edificadas como depósito de víveres e servem de referencial para situar o ouvinte-leitor no tempo, no espaço e na onomástica dos fatos. Os nomes das cidades parecem desconectados do Faraó não mencionado por nome (PIXLEY, G. V., Êxodo, p. 18-21).
} 
exércitos do Faraó no mar dos juncos (Ex 14,1-31). Toda essa dinâmica, porém, foi intensificada pelas objeções de Moisés ao seu chamado e missão.

\section{Texto segmentado e notas de crítica textual ${ }^{3}$}

E disse YHWH:

"Eu vi, certamente, a penúria do meu povo, que está no Egito, e ouvi o seu grito por socorro, diante dos que o tiranizam, porque conheço as angústias dele ${ }^{[a]}$.

Então, desci ${ }^{[a]}$

para libertá-lo da mão dos egípcios

e para fazê-lo subir, do meio dessa terra, para uma terra boa e espaçosa, para uma terra que corre leite e mel; para o lugar dos cananeus e dos heteus, dos amorreus, dos ferezeus, dos heveus e dos jebuseus ${ }^{[b]}$. E ora, eis que o grito dos filhos de Israel veio 9a a mim e também vi a opressão pois os egípcios são os seus opressores.

E, agora, anda!

Mando-te ao Faraó, e faças sair ${ }^{[a]}$ o meu povo, os filhos de Israel do Egito."

Então disse Moisés a 'Elōhîm:

$7 \mathrm{a}$

$7 \mathrm{~b}$

$7 \mathrm{c}$

$7 d$

7 e

$8 \mathrm{a}$

$8 b$

$8 \mathrm{c}$

d

. 
"Quem sou eu para ir ao Faraó

e como farei sair os filhos de Israel do Egito?"

E respondeu ${ }^{[\mathrm{a}]}$ :

"Porque estarei contigo

e isto será o sinal para ti,

que eu te mandei:

Quando fizeres sair o povo do meio dos egípcios,

servireis a 'Elōhîm sobre este monte."

E disse Moisés a 'Elōhîm:

"Eis que eu irei aos filhos de Israel

e direi para eles:

'Elōhê de vossos pais enviou-me a vós.

Mas me dirão:

'Qual é o nome dele?'

Que direi para eles?’"

Então, respondeu 'Elōhîm a Moisés:

[a“'Sou quem Sou!"a]

E acrescentou:

“Assim dirás para os filhos ${ }^{[\mathrm{b}]}$ de Israel:

Eu Sou me mandou a vós."

E disse 'Elōhîm a Moisés:

“Assim dirás aos filhos de Israel:

YHWH, 'Elōhê de vossos pais,

'Elōhê de Abraão, 'Elōhê ${ }^{[a]}$ de Isaac

e 'Elōhê de Jacó, mandou-me a vós.

Este é meu nome para sempre

e está é minha memória de geração em 15e geração $^{[b]}$."
$11 \mathrm{~b}$

$11 \mathrm{c}$

$12 \mathrm{a}$

$12 \mathrm{~b}$

$12 \mathrm{c}$

$12 \mathrm{~d}$

$12 \mathrm{e}$

$12 \mathrm{f}$

$13 \mathrm{a}$

$13 b$

$13 \mathrm{c}$

$13 d$

$13 \mathrm{e}$

$13 \mathrm{f}$

$13 \mathrm{~g}$

$14 \mathrm{a}$

$14 b$

$14 \mathrm{c}$

$14 d$

$14 \mathrm{e}$

$15 \mathrm{a}$

$15 b$

$15 \mathrm{c}$

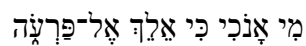

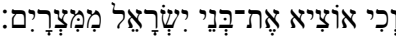

וּיָאמֶר

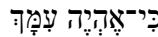

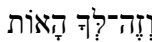

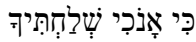

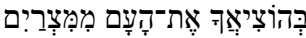

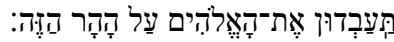

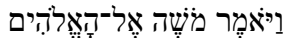

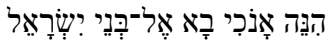

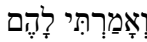

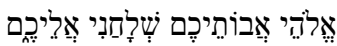

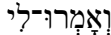

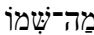

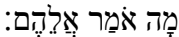

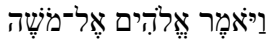

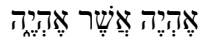

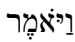

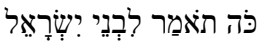

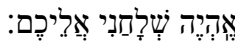

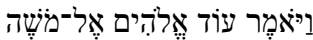

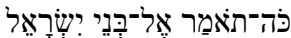

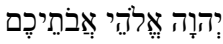

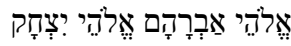

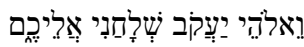

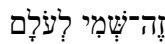

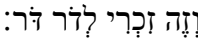


v. 7 (angústias dele ${ }^{[\mathrm{a}]}$ ): O Pentateuco Samaritano e a Vulgata trazem no singular: "angústia dele". Já a Septuaginta, a Peshitta, o Targum e o Targum do pseudo Jônatas trazem o sufixo no plural, "angústia deles". A primeira mudança não considera "povo" como um coletivo. A segunda explica-se pelo contrário, pois "povo" teria sido considerado um coletivo. $\mathrm{O} \mathrm{TM}^{\mathrm{L}}$ não precisa ser visto como uma testemunha textual diferente das demais ou vice-versa. O uso do substantivo plural intensifica o sofrimento e o sufixo no singular segue a dinâmica do coletivo "povo" sem maiores problemas.

v. $8\left(\operatorname{desci}^{\mathrm{a}{ }^{[a]}}\right)$ : A fim de enfatizar a ação divina, o Pentateuco Samaritano traz o verbo no coortativo, "quis descer", procurando concordar com a ação de YHWH, segundo uma lógica sequência de coortativos, por exemplo, nas ações contra Sodoma e Gomorra em Gn 18,21. O qal wayyiqtol do TM ${ }^{\mathrm{L}}$, porém, está bem empregado, pois segue a sequência verbal do v. 7 .

v. 8 (jebuseus $^{[\mathrm{b}]}$ ): O Pentateuco Samaritano e a Septuaginta trazem um acréscimo significativo em relação ao $\mathrm{TM}^{\mathrm{L}}$, pois, além da referência aos "jebuseus", a lista dos povos termina com os "gergeseus". A variante é uma adequação à lista contida na promessa de Deus a Abraão segundo o que está dito em Gn 15,20-21 e concorda, também, com a lista presente em Dt 7,1; Js 3,10; 24,11. Difícil dizer a razão para a omissão dos "gergeseus" na lista do TM ${ }^{\mathrm{L}}$.

v. 10 (faça sair ${ }^{[\mathrm{a}]}$ ): O Pentateuco Samaritano, a Septuaginta e a Vulgata não trazem o verbo no imperativo hifil masculino singular, mas no hifil w ${ }^{e}$ qatal na $2^{\mathrm{a}}$ do masculino singular, "e farás sair". Essa variante melhora a sucessão temporal. Do ponto de vista teológico, o imperativo com a ordem de Deus dada a Noé após o dilúvio $(\mathrm{Gn} 8,17)$. O $\mathrm{TM}^{\mathrm{L}}$ pode ser mantido sem maiores problemas.

v. 12 (E respondeu $\left.{ }^{[a]}\right)$ : A Septuaginta, considerada original, optou por definir o sujeito e o objeto do verbo: "mas Deus falou a Moisés, dizendo". Já uma variante grega da Septuaginta, em minúsculo, traz: "mas o Senhor falou a Moisés, dizendo". A Peshitta e a Vulgata definiram o objeto do verbo usando pronome. As variantes possuem um texto maior, base suficiente para manter o $\mathrm{TM}^{\mathrm{L}}$.

v. 14 ([a Sou quem Sou $\left.{ }^{\mathrm{a}]}\right)$ : A revelação do nome de Deus, em hebraico, abre margem para várias possibilidades de tradução. A Septuaginta, por isso, optou por uma tradução interpretativa: "Eu sou o existente" ( $\dot{\varepsilon} \gamma \omega \dot{~ \varepsilon i ̉ \mu ~ o ́ ~} ̋ v)$. Contudo, o verbo hāyâ não possui o particípio, de modo que a opção da Septuaginta se justifica, pois a partícula relativa, nessa construção, permite que 
o segundo verbo seja entendido como um particípio. A Septuaginta fez a mesma coisa na resposta que YHWH entregou para Moisés dizer aos filhos de Israel.

v. 14 (para os filhos ${ }^{[b]}$ ): Muitos manuscritos em hebraico e o Pentateuco Samaritano corrigem, mudando a preposição, de $ל$ אל para apoiados, talvez, nos v. 13.15, mas esta mudança não altera o sentido. Ex 6,6 possui a mesma construção.

v. 15 (Deus $^{[\mathrm{ad}]}$ ): O Pentateuco Samaritano e a Septuaginta, por questões gramaticais, introduzem a conjunção aditiva ao construto 'elōhê (ואלהי): o mesmo se ocorre nos vv. $6^{[\mathrm{b}]} \cdot 16^{[\mathrm{a}]} ; 4,5^{[\mathrm{b}]}$.

v. 15 (geração $^{[\mathrm{b}]}$ ): O Pentateuco Samaritano corrige o sintagma e acrescenta a conjunção waw. Algo comum, pois o sintagma, com waw, ocorre em vários Salmos $(33,11 ; 49,12 ; 77,9.13)$. Apesar de único no $\mathrm{TM}^{\mathrm{L}}$ o sintagma, sem a conjunção, não interfere na compreensão de Ex 3,15.

\section{Delimitação e estrutura da seção}

Ex 3,6 concluiu a seção anterior com a atitude de Moisés, velando o rosto diante da divindade. ${ }^{4}$ Ex 3,7 abre-se com uma fala direta de YHWH àquele que está em atitude de total reverência. YHWH revela que está ciente da situação que assola e aflige o "seu povo" no Egito. São retomados elementos de Ex 2,2325. ${ }^{5}$ Para o ouvinte-leitor, essa notícia, portanto, não é nova, mas para Moisés "revive", nele, mais do que lembranças, pois evoca parte do drama da sua vida que o obrigou à fuga do Egito.

\footnotetext{
${ }^{4}$ Ex 3,1-4,18 pode ser subdividido em cinco seções: 3,1-6; 3,7-15; 3,16-22; 4,1-9; 4,10-18. A referência a Jetro abre $(E x 3,1)$ e fecha $(E x 4,18)$ o relato dessa experiência, marcada por diálogos entre Moisés e YHWH (COATS, G. W., Exodus, p. 34-39).

${ }^{5}$ Quando se compara Ex 2,23-25 com Ex 3,7-9, percebe-se que os dois textos são provenientes de tradições diferentes, mas possuem vocabulário, conteúdo e motivos afins: os filhos de Israel estão gemendo por causa da dura servidão e estão gritando por socorro à divindade que, no primeiro relato, é denominada 'Elōhîm e, no segundo relato, de YHWH. A dura servidão e o grito de socorro são elementos suficientes para que se instaure um procedimento jurídico: um rîb entre YHWH/'Elōhîm e o Egito. Assim, a questão chegou aos ouvidos do Juiz divino que decidiu intervir porque empenhou a sua palavra através da aliança (berît), selada com os seus eleitos: Abraão, Isaac e Jacó (Ex 2,24; 3,15-16; 4,5 apontam para Gn 17; 26,1-6; 28,1-22). Deus honra a aliança estabelecida com os patriarcas, são laços jurídicos "indissolúveis". Contudo, a narrativa de Ex 2,23-25 parece encontrar a sua continuação lógica em Ex 6,2-9, que se verifica, particularmente, pelo uso de berît, ausente de Ex 3,1 a 6,1 e que determina as razões para acontecer a intervenção divina.
} 
Embora o campo semântico do "ver" esteja presente nos vv. 7.9, novos elementos foram revelados ao interlocutor Moisés. Percebe-se que se passa da temática da sarça ardente à temática da revelação dos elementos que implicarão na vocação e missão de Moisés. Estas serão acompanhadas pelas credenciais da presença divina, que revelará algo de si a Moisés. É a resposta dada, por quem vocaciona e envia em missão, à pergunta feita por Moisés e que diz respeito ao nome do mandante, "Sou o quem Sou", ponto alto dessa seção (v. 14).

Ao lado da mudança temática, existe o retorno a um lugar específico, o Egito, e a uma situação de penúria em que se encontram os filhos de Israel. É YHWH quem revela a Moisés a situação dos seus irmãos. $\mathrm{O}$ algo a ser feito, enquanto projeto, faz de Moisés o executor do que YHWH planejou realizar a favor do seu povo. Nesse contexto, a primeira objeção é feita através de perguntas que preparam a revelação do nome divino: "Quem sou eu para ir ao Faraó e para que faça sair os filhos de Israel do Egito?"; "Qual é o nome dele?" e "Que coisa direi a eles?" (Ex 3,11.13).

Ex 3,15 encerra a seção com uma fala de YHWH/Elōhîm, na primeira pessoa, ratificando o conteúdo dos vv. 6.13 e que fora tratado no v. 14, usando o mesmo argumento, mas acrescentando as informações de uma exigência que intercepta $\mathrm{o}$ ato de reconhecimento feito por Moisés ao cobrir o rosto diante do que ouviu: "Eu sou o Deus do teu pai $($ Ex 3,6)... YHWH, Deus de vossos pais... este é o meu nome para sempre e esta é minha memória de geração em geração". ${ }^{6}$

Assim, Ex 3,15, ao mesmo tempo que identifica o Deus dos patriarcas ('Elōhîm) com YHWH, é uma clara resposta para a pergunta sugerida por Moisés como certa de ser feita pelos filhos de Israel, quando ele se apresentar. Por isso, o v. 15 pode ter um valor de intensidade no argumento usado por YHWH para convencer Moisés. No fundo, é o argumento do narrador para convencer seu ouvinte-leitor a não ter dúvidas quanto à fé em YHWH, o 'Elōhîm que vê, ouve e decide libertar.

De acordo com a lógica interna, Ex 3,7-15 pode ser dividido em três subseções:

vv. 7-10: YHWH domina a cena, mostrando ao seu interlocutor que existe uma situação que precisa ser modificada. Passa-se da constatação à decisão de mudar essa situação. A vontade de YHWH, porém, vai além, porque

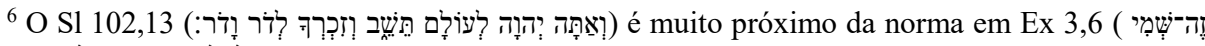

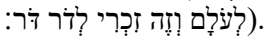


envolve o interlocutor Moisés, fazendo-o protagonista coadjuvante na execução da divina decisão.

vv. 11-12: A cena é dominada por um diálogo em torno dos primeiros sinais de objeção por parte de Moisés. O ouvinte-leitor começa a perceber que o eleito é temeroso e possui fraquezas a serem superadas pelo critério "do mais forte ao lado do mais fraco", capacitando-o para realizar a missão. Não há o que temer, "pois eu estarei contigo". Moisés percebeu a gravidade e a complexidade da decisão que o envolvem na realização da vontade divina. Estes sinais de objeção servem para introduzir o ápice desta seção: a revelação do nome divino e sua correspondência com a fé transmitida pelos patriarcas. Nos vv. 11-12, predomina o substantivo comum 'Elōhîm no estado construto.

vv. 13-15: A cena gira em torno da revelação do nome divino, resposta direta e objetiva às hesitações de Moisés. Vendo que a sua dúvida-objeção obteve uma pronta resposta, acompanhada, inclusive, de um sinal, começa a ser ajudado a aceitar e a assumir a missão. A revelação do nome é um acontecimento que deverá ser perpetuado. Do momento em que Moisés der a conhecer aos filhos de Israel quem o envia, saberão o nome que devem invocar. Será neste nome que a libertação se realizará.

Ao que Moisés diz, segue-se a resposta de YHWH diante do duplo problema: "Qual é o seu nome?" e "Que coisa direi a eles?" (v. 13)... "E respondeu 'Elōhîm a Moisés", isto é, apresenta-se a solução do problema esclarecido ao máximo. Para a primeira pergunta, a resposta foi: "Sou quem Sou". Para a segunda pergunta se deu um complemento: "Assim dirás para os filhos de Israel: Eu Sou me mandou a vós" (v. 14). A tudo isso, YHWH acrescenta o significado para o nome revelado: É o modo novo como será invocado, para sempre, por todas as gerações dos filhos de Israel (v. 15).

\section{Análise das subseções}

O narrador introduziu, em Ex 3,7-15, as falas de YHWH e de Moisés. A função do narrador é parecida a de um mediador ou intermediário entre duas partes que buscam se conhecer ou tratar de um assunto que demanda uma solução urgente: a libertação dos filhos de Israel do Egito e sua condução para a "terra em que correm leite e mel" (v. 8).

O ouvinte-leitor não tem dificuldades para perceber que YHWH domina a cena, apesar de Moisés interagir após a revelação do nome. O interlocutor 
demonstra que ele não é, por nada, ingênuo diante da missão que está sendo colocada diante dele.

Apesar disso, o ritmo é dado pela parca, mas importantíssima, ação do narrador. Sem a sua mediação, nas fórmulas, ${ }^{7}$ que introduzem as falas de YHWH e de Moisés, o ouvinte-leitor não seria envolvido na cena. Contudo, de Ex 3,16, em diante, YHWH será o único protagonista e Moisés reaparecerá apenas nas novas objeções, tentando evitar a missão e dissuadir YHWH, dando a entender que ele, realmente, não é apto e capaz de assumir essa grande tarefa. ${ }^{8}$

Outro elemento relevante da narrativa encontra-se na relação estabelecida entre causa e efeito. No v. 7, o povo grita diante dos opressores e YHWH escuta; no v. 8, o povo está oprimido no Egito e YHWH decide libertálo e conduzi-lo para a terra boa e espaçosa; no v. 9, o grito chegou aos ouvidos de YHWH e a opressão foi vista por ele; no v. 10, Moisés é a decisão-resposta de YHWH ao grito que ouve e à opressão que vê do seu povo; no v. 12, YHWH está com Moisés, o acompanha com um sinal, e os libertos prestarão culto a 'Elōhîm no monte santo; no v. 13, Moisés diz: "vou e digo"... e os filhos de Israel questionam; v. 14, YHWH responde revelando o seu nome e ratifica o envio; enfim, no v. 15, YHWH acrescenta, à resposta já dada, o mesmo elemento decisivo que dera a Moisés e que o fizera esconder sua face: os filhos de Israel terão um nome divino para invocar de geração em geração.

Nessa relação, entre causa e efeito, a atenção aos verbos é igualmente fundamental. No v. 7: "vi" e "ouvi"; no v. 8: "desci para libertar"... "fazer subir"; no v. 9: "veio" e "vi"; no v. 10: "vai", "mandarei", "faze sair"; no v. 11: "ir", "faça sair"; no v. 12: "estou contigo", "envio", "fizer sair", "servireis"; no v. 13: "vou", "digo", "enviou-me", "me dirão", "que direi"; no v. 14: "Sou quem sou", "dirás", "eu sou me enviou'; no v. 15: "dirás", "enviou-me". Percebe-se que os verbos usados giram em torno de uma ação principal devido à situação urgente que precisa ser resolvida: "fazer sair do Egito". Todo o

7 v. 7: "e disse YHWH”; v. 11: "e disse Moisés a 'Elōhîm"; v. 12: "e disse"; v. 13: "e disse Moisés a 'Elōhîm"; v. 14: "e disse 'Elōhîm a Moisés"; v. 15: "e disse ainda 'Elōhîm a Moisés".

${ }^{8}$ A postura de resistência de Moisés vem expressa através de cinco objeções, vencidas pelo diálogo com YHWH que oferece sinais. Primeira objeção: "quem sou eu" (Ex 3,11). Segunda objeção: "quem és tu?" (Ex 3,13). Terceira objeção: "não acreditarão em mim" (Ex 4,1). Quarta objeção: "não sei falar" (Ex 4,10). Quinta objeção: "envia outro" (Ex 4,13). Moisés, como acontece com outros eleitos (Jz 6: Gedeão e Jr 1,4-10: Jeremias), reluta diante do chamado. A hesitação, na narrativa da vocação mosaica, baseia-se na necessidade humana de sinais e de reafirmação pessoal (DOZEMAN, T. B., Exodus, p. 132-133). 
desenvolvimento sucessivo da narrativa, do êxodo do Egito à morte de Moisés nas estepes de Moab, refletem as consequências da aceitação e execução da sua vocação e da missão.

Versículos 7-10

O gesto de Moisés, velando a própria face, permite que seus ouvidos estejam abertos para ouvir YHWH que não tem olhos fechados para a situação de penúria do seu povo que está no Egito. Estado de penúria, grito por socorro, opressão e angústia, são sinais de opressão social e retratam a urgência que impele YHWH a se comunicar com Moisés e fazer dele uma resposta salvífica para o seu povo. ${ }^{9}$

Moisés é alguém que vislumbra os dois lados. Ele conhece o povo e conhece os seus opressores. É a pessoa que reúne, em si, os elementos necessários para empreender a tarefa libertadora e que será capacitado para tal, porque vai voltar para o Egito e lá vai agir em nome do Deus de seu povo.

Estar no Egito não é uma simples referência de local, mas pode soar como uma queixa divina. Que faz "meu povo" no Egito? No âmbito do Pentateuco, tal pergunta não seria descabida. O povo está no Egito por pura permissão divina (Gn 46,2-4). A busca por condições favoráveis à vida, fugindo da fome, está na raiz da questão. Por que YHWH permitiu a fome e com ela a ida do povo para o Egito? Por que não propiciou o necessário para a subsistência do seu povo na terra, para que este não tivesse que deixá-la? Por que retoma o desejo de dar-lhes uma terra boa?

No ciclo de Abraão e Sara, relata-se que uma fome na terra levou o patriarca para o Egito, a fim de escapar da morte (Gn 12,10). No "ciclo de Isaac", se dá a mesma situação: uma fome na terra (Gn 26,1). Existe, porém, uma proibição, por parte de YHWH, para que Isaac não desça ao Egito. ${ }^{10}$

9 Os substantivos "pobreza”, "indigência”, "penúria” traduzem bem o substantivo ‘ŏnî, seu correlato é 'ănî, provenientes da raiz " $n h$ : "ser oprimido", "estar angustiado", "estar em situação de penúria e miséria" (Ex 22,24; Is 3,14.15; Jr 22,16; Ez 18,12.17; Am 8,4; Jó 24,4.9.14; S1 9,19; Pr 15,15 - MARTIN-ACHARD, R., ענה 'nh, p. 435-447).

${ }^{10}$ A proibição de Isaac descer ao Egito (Gn 26,2-6) tem a ver com a garantia da propriedade adquirida por seu pai Abraão dos filhos de Het (Gn 23). De igual modo, a permanência de Nacor em Ur, pois Taré não o levou consigo, serviu para garantir a propriedade ( $\mathrm{Gn} 11,31)$, e para fundamentar a busca da futura esposa para Isaac (Gn 24). "Isaac é o único patriarca que dá aos 
Enfim, no ciclo de Jacó-José, o problema da fome se repete (Gn 42,1-2), a solução virá pelas mãos de José que já está no Egito, porque já fora vendido aos madianitas pelos seus irmãos (Gn 37,28.36).

Os textos que narram a entrada de Jacó, com seu clã, no Egito, refletem diferentes tradições a respeito do fato, mas concordam com o sentido: José foi o responsável pela saída de Jacó de Canaã e da sua entrada no Egito (Gn 46,16.28-34; 47,5-12.27; 50,14.22-26). Gessen, entre Canaã e o Egito, foi o local escolhido para instalar os filhos de Israel. ${ }^{11}$

Então, o Egito figura como um lugar em que Israel buscava auxílio e refúgio. Fazia parte das suas estratégias para vencer as intempéries da vida, mas acabava vítima de suas escolhas. O livro de Êxodo, do ponto de vista literário, abre-se (Ex 1,1-7), com a notícia do final de Gênesis (50,22-26), falando que a opressão dos filhos de Israel teve início com a mudança política do rei do Egito (Ex 1,8). A multiplicação demográfica (Gn 1,28; 9,1), e o poder adjunto tornam-se, ao lado do desconhecimento do novo rei do Egito sobre José, as possíveis causas da opressão dos filhos de Israel (Ex 1,9-13). ${ }^{12}$

A nova descoberta para Moisés consiste na missão que lhe será confiada e nas credenciais que ele terá para realizar tal missão. A revelação do nome divino tem uma estreita ligação com a existência do povo e com o desejo de YHWH colocar um fim no sofrimento do seu povo. Em contrapartida, os egípcios, diante dos feitos de YHWH para libertar o seu povo, darão um forte grito, sem igual, quando tiverem, nos braços, os seus primogênitos mortos (Ex $11,6 ; 12,30)$.

O contexto da morte dos primogênitos do Egito abala a consciência do ouvinte-leitor, mas este feito, atribuído à ação de YHWH a favor do seu povo, insere-se no uso da lei do talião (Ex 21,23-24). Como o Egito buscou eliminar os primogênitos dos filhos de Israel, da mesma maneira teve sobre si a morte dos seus primogênitos. Isto não seria necessário, se o Faraó não tivesse se obstinado diante do pedido cultual e dos sinais realizados por Moisés. O povo eleito devia partir para oferecer um sacrifício a YHWH, mas como não lhe foi facultado este

seus descendentes o pleno direito à posse da terra, porque nunca a deixou" (SKA, J-L., O Antigo Testamento, p. 41).

${ }^{11} \mathrm{Gn} 45,10 ; 46,28.29 .34 ; 47,1.4 .6 .27 ; 50,8 ;$ Ex 8,18; 9,26; Js 10,41; 11,16; 15,51 .

12 Uma leitura atenta de Gn 47,13-26 permite ver, sob a perspectiva da ação de José, uma base para a aversão contra os filhos de Israel e sua relação com o êxodo do Egito (FERNANDES, L. A., Porque morreremos na tua presença?, p. 125-130). 
pedido, o sacrifício se deu no próprio Egito, com o sacrifício de todos primogênitos, dos humanos e dos animais. Fica a lição, que poderia ter sido evitada pela obediência à voz e ao desejo de YHWH, o Deus dos filhos de Israel.

YHWH desceu para libertar o seu povo, a fim de que, liberto, ele pudesse subir do Egito, terra da opressão, para Canaã, a terra boa e espaçosa. O movimento é, do ponto de vista divino, descendente (kenótico) e, do ponto de vista do povo, ascendente. Esta parábola é um movimento que corresponde tanto ao aspecto geográfico quanto ao aspecto teológico.

"E desci"... de onde? Dos céus, poderia ser a resposta, pois terra e céus são os pólos da criação (Gn 1,1-2). No livro de Gênesis, dois textos denotam este movimento: a) Em Gn 11,5, no episódio da torre de Babel, YHWH desceu para ver as intenções dos homens; b) Em Gn 18,21, YHWH desceu para averiguar a maldade que subiu até ele de Sodoma e Gomorra. ${ }^{13}$ Depois de Ex 3,8, onde YHWH/'Elōhîm é o sujeito, só em Ex 19,11 descerá numa nova aparição, para, enfim, descer, tomar posse da tenda-santuário, de modo a habitar e a peregrinar com o seu povo pelo deserto (Ex 40,34).

A terra de destino é boa, porque "corre leite e mel", e é espaçosa, porque nela habitam muitos povos: "lugar dos cananeus, dos heteus, dos amorreus, dos ferezesus, dos heveus e dos jebuseus". Por isso, é uma terra cobiçada, contemplada como uma possibilidade de vida para um povo que, reduzido à situação servil, clamou porque desejava se reerguer e retomar a vida. A condição favorável da terra se torna condição sine qua non para que o povo tenha, igualmente, uma condição digna para existir.

Estranho que YHWH queira tirar um povo já instalado em Gessen para levá-lo para uma terra já habitada, criando o obstáculo da "desocupação" dos povos já instalados. Seria compreensível se o povo voltasse para o território que, de fato, "lhe pertence", Hebron, região onde se encontra a gruta de Macpela. Local comprado e, portanto, pertencente aos descendentes de Abraão

\footnotetext{
${ }^{13}$ Contra Sodoma e Gomorra se eleva a YHWH um grito, que pelo contexto poderia ser colocado nos lábios de Ló $(\mathrm{Gn} 18,20)$. Esaú, vendo que perdera a bênção de seu pai, grita, na esperança de que seu pai o abençoasse (Gn 27,34). O mesmo grito, o povo eleito eleva ao perder a arca da aliança para os filisteus (1Sm 4,14-17). Este é o grito dos que, numa situação de guerra, contemplam o seu aniquilamento como castigo, como nos dias de Edom, de Sodoma e Gomorra (Jr 49,7-22).
} 
(Gn 23,19-20). A ação de "despejo", contudo, tem a ver com uma afirmação teológica: "minha é a terra" (Lv 25,23). ${ }^{14}$

Percebe-se que se repetem e se ampliam as informações já dadas no v. 7. O advérbio, que abre o v. 9, é relevante, pois indica que uma resposta deve ser dada. A situação não pode se prolongar e a solução é urgente. Ao lado disso, o aspecto relacional aparece bem forte, pois YHWH revela que o clamor foi feito a ele e está devidamente justificado: "vi a opressão que os egípcios lhes oprimem”. Não importa a distância geográfica (Horeb - Egito), pois YHWH está ao alcance do seu povo. Nesse sentido, YHWH se colocou como testemunha auricular e ocular, pois ouviu o clamor e viu a opressão.

Outro elemento importante reside no fato de que YHWH se posicionou a favor dos filhos de Israel, porque estão oprimidos, mas, nem por isto, se colocou contra os egípcios. Isso acontecerá, mas como fruto da obstinação e intransigência, vistas e anunciadas como dureza do coração do Faraó. ${ }^{15}$

Toda a fala de YHWH, até o presente momento, daria a entender que ele mesmo se ocuparia da situação. É curioso, pois, enquanto YHWH se demonstrou atento ao que estava acontecendo com os filhos de Israel, Moisés não apresentou algum tipo de reação; pareceu que estava apático e indiferente à dor e ao sofrimento dos seus irmãos. Talvez, por isso, o v. 9 tenha retomado o conteúdo do v. 7, na esperança de que Moisés manifestasse alguma reação solidária.

Visto que não se pronunciou a respeito, YHWH, então, determinou a sua missão. São três ações em sequência. Pela primeira ação, Moisés entendeu que devia retornar ao Egito, local que há muito tempo ficara no passado. Voltar ao Egito tem um peso enorme pois evoca lembranças conflitantes. Ao mesmo tempo, na segunda, significa ter que deixar a vida que havia assumido nos

\footnotetext{
${ }^{14}$ A terra, do ponto de vista teológico, é fruto da ação criadora de Deus (Gn 1,1); logo, ela pertence a Deus (Ex 9,29; Dt 10,9; Sl 24,1; Ne 9,6), mas foi criada para ser habitada (Gn 1,28; 8,$17 ; 9,1$; Is 45,18). Em Lv 25,23-28 "vem estabelecido um princípio fundamental: a terra não se vende para sempre. O motivo de tal princípio funda-se sobre um dado fundamental da teologia bíblica: Deus, enquanto criador, é o dono da terra, por conseguinte pode confiá-la do seu agrado a quem quiser e segundo as suas condições (já as promessas feitas a Abraão em Gn 15,7 são uma antecipação do quanto Deus fará com o povo judeu, Ex 3,8; Dt 7,1); em consequência de tal princípio, todos devem se considerar como imigrantes" (DEIANA, G., Levitico, p. 271-272).

${ }^{15}$ Há três formulações distintas: "YHWH/'Elōhîm endureceu o coração do Faraó" (Ex 4,21; 7,3; 9,12.14; 10,1.20.27; 11,10; 14,4.8). "Faraó endureceu seu coração" (Ex 7,23; 8,11.28; 9,34); "o coração do Faraó se endureceu" (Ex 7,13.14.22; 8,15; 9,7.35). Cada uma dessas formulações merece a sua devida compreensão. Veja-se GROSS, F., O Coração do Faraó, p. 13-58.
} 
últimos 40 anos junto à sua esposa e filhos no que diz respeito a Jetro, seu sogro. $\mathrm{Na}$ terceira, YHWH expressa o que quer.

Quanta coisa não deve ter passado pela cabeça de Moisés. Por que decidiu adentrar no deserto com o rebanho do seu sogro? É como se costuma dizer: "Se arrependimento matasse!" Além de voltar, teria que enfrentar a pessoa mais poderosa de todo o Egito, o Faraó. Foi a este que YHWH enviou Moisés com uma tarefa nada simples: anunciar, convencer e fazer sair os filhos de Israel do Egito.

\section{Versículos 11-12}

Na primeira parte do v. 11, o narrador cedeu a fala a Moisés, a fim de que, finalmente, pudesse mostrar que não ficou apático ao que ouviu sobre a penosa situação dos seus irmãos de raça e sobre a intenção libertadora de YHWH. A razão é óbvia e por dois motivos. Em primeiro lugar, porque Moisés entrou em diálogo com o próprio Deus, que não lhe permitiu vê-lo, mas lhe fez ouvir a sua voz e permitiu responder ao que ouviu. YHWH concedeu a Moisés a graça de ouvir e de interagir com ele. Em segundo lugar, porque o conteúdo da fala divina, isto é, a vocação e a missão, que YHWH confiou a Moisés, não poderia ficar sem uma justa e adequada resposta.

Moisés não tinha como ficar apático ou se esquivar diante de tudo o que ouviu sobre o sofrimento dos seus irmãos e sobre a proposta libertadora de YHWH. Assim, teve início um diálogo, pois, até o momento, apenas YHWH havia falado. Disse quem era, o que sabia da situação dos filhos de Israel no Egito, dos habitantes de Canaã e o que queria de Moisés.

É preciso pensar no impacto que subjaz nessa revelação, YHWH está disposto não só a dialogar com o ser humano, mas a revelar a sua identidade, manifestando que quer o envolvimento de Moisés com os seus divinos propósitos. É, assim, que Deus se entrega ao ser humano, pois, além de se revelar, lhe fala como a um amigo e se entretém com ele, instaurando uma relação íntima e interpessoal. ${ }^{16}$

Contudo, o ouvinte-leitor precisa lembrar que existe um anteparo entre Moisés e YHWH: a sarça ardente, que funciona como um véu que protege e

\footnotetext{
${ }^{16}$ Dei Verbum, n. 2. O ser humano, por sua vez, é chamado não apenas a conhecer Deus, mas a participar dos seus propósitos, porque, sendo o seu criador, é o único que pode mostrar à sua criatura a via que conduz à sua realização pessoal.
} 
impede que a divindade seja vista face a face por Moisés (Ex 33,18-23). Isto significa que Deus se revela na justa medida, de acordo com as capacidades de suportação e de compreensão do ser humano. Dado relevante é que são dois seres pessoais, de naturezas distintas, que estabeleceram uma relação e entraram em diálogo.

YHWH, que havia banido Adão e Eva do paraíso, devido à desobediência (Gn 3,22-24), admitiu, novamente, o ser humano diante da sua divina presença e com ele se comunicou. E fez mais, veio pessoalmente ao seu encontro. Há, porém, uma diferença. No paraíso, YHWH/'Elōhîm andava pelo jardim e se entretinha com os progenitores da humanidade. Aqui, falou com Moisés por detrás de uma sarça, um arbusto do deserto, visto que manteve a sua palavra ao expulsar o ser humano do jardim, colocando-o num lugar em que existe espinhos e cardos, isto é, um deserto (Gn 3,17-18). ${ }^{17}$

Então, Moisés contestou a proposta de YHWH com uma pergunta bem elaborada e pautada sobre uma dupla categoria: a sua ínfima identidade no confronto com a sublime identidade do Faraó e a missão libertadora dos filhos de Israel em relação ao Egito. Pode-se dizer que, assim como Moisés estava em desvantagem em relação ao Faraó, o Egito estava em vantagem sobre os filhos de Israel. Moisés estava para os filhos de Israel como o Faraó estava para os egípcios.

Pela índole da pergunta, nota-se que Moisés não só entendeu o plano de YHWH, mas fez uma apurada reflexão quanto à intenção divina. Para Moisés, não pareceu ser um problema regressar ao Egito. O cerne da questão, portanto, aparece girando em torno da discrepância entre quem é Moisés e quem é o Faraó. Um confronto humano, por certo, desproporcional. É como "Davi diante de Golias".

$\mathrm{Na}$ narrativa, esta foi a primeira objeção que Moisés colocou à missão que YHWH the estava confiando, pois reconheceu a natureza e a grandeza do obstáculo que deveria enfrentar. O ser humano, geralmente, se retrai quando se dá conta dos desafios que deverá superar; mas pode-se dizer que é um modo para não se arvorar ao que excede às próprias capacidades. Moisés sabia que era incapaz, mas não sabia que estava sendo capacitado por YHWH para uma missão, humanamente, invencível.

\footnotetext{
${ }^{17}$ Deus veio ao encontro do ser humano no local para o qual o havia banido, porque este se encontrava sob uma determinação: não podia voltar ao jardim. O motivo: estender de novo a sua mão e usurpar do fruto da árvore da vida para não experimentar a morte (Gn 3,22-24). Este fruto foi salvaguardado por YHWH para que o ser humano o recebesse como dom e sinal da sua graça salvífica.
} 
Moisés não se deu conta, mas a sua identidade fora devidamente revelada por YHWH, pois ao dizer quem é (teologia), revelava quem Moisés é (antropologia). Pode-se ver, facilmente, a resposta para a pergunta "Quem sou eu...?": Moisés é quem está falando com o 'Elōhê de seu pai, o 'Elōhê de Abraão, de Isaac e de Jacó. Na verdade, poder-se-ia inverter a pergunta: Quem é o Faraó diante de Moisés, representante eleito do Deus de seu povo? Isto ficará bem claro em todo o desenvolvimento dos fatos que levarão ao êxodo dos filhos de Israel do Egito e a um resultado desconcertante: o Faraó humilhado diante de YHWH, 'Elōhê de Moisés e do seu povo.

O diálogo procede, o narrador cedeu a fala a 'Elōhîm (v. 12a). Ante ao obstáculo, posto por Moisés através de uma ponderada questão, YHWH/'Elōhîm apresentou o que passa a ser determinante na Sagrada Escritura: a certeza da sua presença e divina assistência na vida e na ação de quem é chamado a uma missão salvífica: "Estarei contigo" (v. 12b). ${ }^{18}$

Para que Moisés, implicado na missão, tivesse certeza dessa promessa, 'Elōhîm ofereceu um sinal (v. 12c). É um modo de penhorar a palavra dada, de demonstrar o seu valor e a sua importância, passando a ter o peso de aliança. ${ }^{19}$

YHWH é o maior interessado em libertar o seu povo e se comprometeu com a missão que atribuiu a Moisés em três passos: ir, se apresentar ao Faraó e fazer sair, do Egito, os filhos de Israel (v. 10). O sinal não tem a ver, nesse momento, com alguma possível dúvida dos filhos de Israel, mas com a hesitação de Moisés. Então, pelo sinal, 'Elōhîm estava dando a Moisés um modo de se certificar da autenticidade da sua palavra e do envio recebido (v. 12c).

A razão é bem simples: enquanto essa dúvida não fosse vencida, Moisés não conseguiria dar um passo na direção da aceitação e da realização da missão.

\footnotetext{
18 Por detrás dessa afirmação é possível entrever a Teologia do Emmanuel, isto é, do "Deus conosco", como profetizado por Is 7,14; 8,8.10 (dado curioso: a Septuaginta não citou a locução 'immanû 'el presente em Is 8,8.10) e que foi assumido por Mt 1,23. É a mesma certeza de fé que Paulo professou e procurou transmitir aos fiéis de Roma: "Se Deus está conosco, quem estará contra nós" (Rm 8,31).

${ }^{19}$ Quem grita espera ser ouvido. O verbo šāma ' possui um valor fundamental na tradição bíblica. Ele significa "escutar" e "obedecer". Os filhos de Israel, pelo šema ' (Dt 6,4-9), só deveria ouvir YHWH, porque é o único capaz de ouvir o seu grito por socorro nas situações de perigo e aflição (S1 107,6; 28). No contexto da aliança, este verbo exerce o sentido de ação bilateral. As partes escutam-se e se comprometem mutuamente. Aquele que garante a proteção ouve o grito dos que lhe pedem proteção e os que pedem proteção alcançam ajuda porque ouvem a voz de quem lhes protege (SCHULT, H., שמע, Diccionario Teologico, p. 1221-1231).
} 
Pela sequência (v. 12ef), o sinal ${ }^{20}$ poderia ser identificado com dois tempos e movimentos, respectivamente no passado, "quando tiveres tirado o povo do Egito" (v. 12e), e no futuro, "servireis a 'Elōhîm sobre esta montanha". Por essa lógica, a divindade apresentou a Moisés um elemento ulterior da missão.

Nada impede de se assumir a experiência que Moisés teve no Horeb como reveladora do sinal oferecido por YHWH/'Elōhîm. Ao colocar o primeiro movimento no passado, YHWH/'Elōhîm já estava assegurando a Moisés o êxito da missão. Isto, por certo, seria suficiente para afastar todo e qualquer medo. Ao colocar o segundo movimento no futuro, YHWH/'Elōhîm estava apresentando a Moisés um objetivo ulterior da missão. Com isso, os filhos de Israel, libertos das mãos do Faraó e do Egito, deveriam passar para as mãos de YHWH, o 'Elōhîm que se revelou a Moisés no Horeb.

\section{Versículos 13-15}

A nova fala de Moisés a YHWH, introduzida pelo narrador (v. 13a), tem um tom de réplica, mas, ao mesmo tempo, atesta uma grande profundidade de reflexão. Para quem não é semita, esse vai e vem no diálogo pode não ter muito sentido, mas para o semita, ele é fundamental. É um "comércio", não de mercadorias, mas de propósitos e de intenções.

Se a YHWH coube a determinação de libertar, a Moisés coube a determinação de aceitar a vontade divina em função da urgência do que estava sendo "barganhado" entre os dois: a libertação dos filhos de Israel das mãos opressoras do Faraó. ${ }^{21}$ Pelo tom da primeira pergunta, parece que Moisés estaria começando a cogitar a possibilidade de aceitar o chamado e a missão. Ao dizer, "quando eu for", Moisés teve em mente a primeira ação dada por YHWH: "E ora, vai" (v. 10a).

De forma inteligente e perspicaz, Moisés sabia, muito bem, que precisaria ter nos lábios palavras convincentes para serem ditas aos filhos de Israel. Como ele estava sendo convencido de que YHWH é o 'Elōhîm digno de

\footnotetext{
${ }^{20}$ A frase: "eu estarei contigo" (v. 12a), não revela apenas a intimidade de 'Elōhîm com Moisés manifestada através dos sinais e no seu poder de intercessão, mas poderia ser o sinal necessário que confirma o eleito.

${ }^{21}$ Os opressores também podem ser subentendidos como os capatazes (Ex 5,6.10.13-14), que deviam exigir dos filhos de Israel a produção diária de tijolos. Em Dt 15,2.3, está a proibição de oprimir o devedor. 2Rs 23,35 retrata a opressão oriunda dos impostos que o rei Yehoyaqîm teve que impor, com força, sobre o povo, para pagar o tributo ao Faraó Necao II (Is 14,4).
} 
crédito, pelo sinal dado, também precisava se tornar digno de crédito para os filhos de Israel no Egito. Nesse sentido, Moisés tinha certeza de que para convencer não podia voltar e se apresentar em nome próprio. Ele compreendeu que a sua missão era uma espécie de embaixada junto aos filhos de Israel que, igualmente, iriam testar as suas intenções.

A libertação implicava em múltiplas questões. A sua credencial era válida, mas tinha que saber mais sobre quem o comissionava. Além do óbvio contido na fala, "o 'Elōhê de vossos pais me enviou a vós", residia um mistério. Moisés “testou” o 'Elōhê de seu pai. É a sedução que envolve o ser humano. Saber o nome de uma divindade, na época, equivalia a ter domínio sobre ela. De forma astuta, Moisés transferiu o que quis saber para os filhos de Israel.

Como Moisés poderia prever que seus irmãos de raça questionariam (v. 13e)? A pergunta, "qual é o seu nome?", seguia na direção do que Moisés, pessoalmente, havia experimentado, pois ouviu ser chamado pelo seu próprio nome duas vezes: "Moisés, Moisés" (v. 4). Se YHWH o conhece por nome, então, para ficar páreo, tinha que saber o nome desse 'Elōhîm. Foi uma audaz colocação. Não foi uma pergunta ingênua. Se YHWH respondesse, Moisés teria a certeza de que não tinha que se preocupar com a missão e poderia sair da presença dessa divindade sem medo de receber alguma retaliação. ${ }^{22}$

Visto que YHWH demonstrou o seu interesse pelos filhos de Israel, a segunda pergunta, "que responderei para eles?", é mais astuta ainda, pois dava a entender que Moisés estaria assegurando de ter o controle dessa experiência. É possível pensar que na mente e no coração de Moisés estivesse uma aflição: Por que YHWH se importa com os filhos de Israel, mas parece não se importar com a minha segurança frente ao Faraó e todo o Egito? Por que Moisés deveria colocar a sua vida em risco pelo seu povo que, no passado, não se demonstrou disposto a acolher a sua preocupação? (Ex 2,13-14).

A fala retorna ao narrador (v. 14a), a fim de revelar que a astúcia de Moisés não foi em vão. Na verdade, só confirmou a sua escolha por YHWH, pois nunca se equivoca quando escolhe. O escolhido é que pode se equivocar e tomar uma direção oposta à sua vocação e missão. Se Moisés, com YHWH, estava se demonstrando tão capaz na argumentação, o que não faria diante do Faraó?

${ }^{22}$ Ex 33,12-17 mostra que Moisés assumiu a sua vocação, venceu suas apatias, e aprendeu a dialogar com YHWH. Na base, está a graça aos olhos de YHWH que conhece o seu eleito por nome (DOZEMAN, T. B., Exodus, p. 727-729). 
Por isso, ao invés de deflagrar a astúcia de Moisés, YHWH deu resposta para as duas perguntas. Para a primeira, "qual é o seu nome?", obteve a resposta: "Sou quem Sou" (v. 14b). ${ }^{23}$ Para a segunda, "que responderei a eles?", a resposta ligou o nome com a missão: "Assim dirás aos filhos de Israel: Eu Sou enviou-me a vós" (v. 14df). YHWH eliminou o primeiro obstáculo e as possíveis consequências.

Autoapresentação de YHWH a Moisés e a declaração aos filhos de Israel se correspondem. Esta verdade fixa-se como exigência, que garante a certeza da presença divina na mente humana e forma uma memória coletiva. Moisés não é parte dos filhos de Israel apenas pela raça, mas, principalmente, pela eleição e divinas promessas feitas aos patriarcas. Moisés é o embaixador de YHWH, 'Elōhê do seu povo e, como tal, agirá, justificando e confirmando o divino mandato.

De geração em geração, perpetuando a memória, se deverá transmitir a verdade associada ao Nome revelado a Moisés. Como YHWH veio ao encontro de Moisés na sarça e não o feriu de morte, de igual modo virá ao encontro do seu povo, possibilitando a vida no local, onde a vida, humanamente dizendo, não pode existir: o deserto. E isto, com uma intenção particular: fazer do seu povo um reino de sacerdotes e uma nação santa (Ex 19,5-6).

\section{Conclusão}

O mísero, quando não tem mais recursos e percebe que ninguém o trata como pessoa, sabe que só tem a Deus por amparo. Grita, do fundo da sua angústia, e busca em Deus conforto, auxílio e refúgio; espera compaixão e justiça, porque seus direitos básicos e necessários foram violados (Sf 2,3; 3,12). Espera-se que o líder se preocupe com os míseros e indigentes (S1 72,4; Zc 9,9). Essa esperança, que alimenta a vida dos que estão relegados à morte, envolveu o chamado e a missão de Moisés.

\footnotetext{
${ }^{23}$ A revelação, "Sou quem Sou", é uma das traduções possíveis para a forma que se encontra no texto em hebraico. Outras seriam, igualmente, válidas: "Sou Aquele que estou sendo"; "Serei Aquele que serei"; "Sou Aquele que fui"; "Fui Aquele que sou". Tais possibilidades apontam para um elemento essencial da natureza de Deus: é atemporal, pois é o Existente por excelência. Existe por si mesmo e não depende de outro para existir. A etimologia do nome divino é discutida (FERRARI, P. L., Il libro dell'Esodo, p. 65-68). Para uma discussão sobre o sentido do Tetragrama Sagrado, YHWH, veja-se: RÖMER, T., A Origem de Javé, p. 33-42; FRANCISCO, E. de F., Tetragrama, Teônimos e Nomina Sacra, p. 65-107.
} 
Ex 3,7-15 contribui com novas perspectivas a partir do contexto preparatório introduzido pela primeira cena (Ex 3,1-6). ${ }^{24}$ Ao ouvinte-leitor foi dado o conhecimento da experiência de Moisés no "monte de 'Elōhîm, o Horeb". Inserido, agora, nessa experiência, são oferecidas novas e ulteriores experiências no "solo do santo" a respeito de Moisés, da sua vocação e missão, de YHWH, do desejo libertador, da revelação do nome e do povo, duramente oprimido no Egito.

Tudo o que Moisés passou a saber sobre a sua vocação e a sua missão diz respeito ao objeto do desejo divino: "meu povo" (Ex 3,7.9). O diálogo que se estabeleceu entre YHWH e Moisés foi intenso, sem precedentes tão claros e diretos. Ao saber dos planos divinos, Moisés passou a saber, igualmente, da situação do seu povo.

Madiã, o deserto, o monte Horeb e revelação do nome divino constituem os elementos chaves da tradição que manterá e veiculará o evento fundamental: a fé na ação libertadora de YHWH, 'Elōhîm dos filhos de Israel. Antes que o povo possa buscar a salvação, precisa perceber e acreditar que a salvação é que vai ao seu encontro através do agente libertador, Moisés. ${ }^{25}$

Com isso, o êxodo é um evento que se torna decisivo a partir da experiência de Moisés no Horeb e que condiz com a sua atual ocupação, pastor do rebanho de Jetro. YHWH, então, quis Moisés como pastor e guia do seu povo. Para que isto acontecesse, Moisés quis contar com um critério decisivo: Em nome de quem ele irá até o Faraó e aos filhos de Israel? Se, por um lado, Moisés é apresentado como digno de "saber" o nome divino, por outro lado, este conhecimento torna-se um peso glorioso que deverá carregar e transmitir aos quais ele está sendo enviado. ${ }^{26}$

\footnotetext{
24 "Perceber, decifrar, entender e dialogar são quatro ações que marcam o desenvolvimento de Ex 3,1-6” (FERNANDES, L. A., Aproximação narrativa a Ex 3,1-6, p. 64).

${ }^{25}$ Os ídolos, feitos de ouro-prata-lenho, são obras das mãos humanas e, por isso, são incapazes de salvar, isto é, de reagirem diante do grito de angústia dos que a eles se dirigem, invocam e buscam ajuda nas aflições e adversidades (1Sm 12,21; S1 115,4; 135,15-18; Is 46,2; Br 6,35-36; Os 8,4; 14,9; Mq 1,7; Zc 13,2).

${ }^{26}$ Deus não necessita do amor humano, pois, em si, não tem necessidades e é Amor, mas quis infundir e encontrar no ser humano a presença do seu divino ser. É o que faz compreender Gn 1,26 e a definição contida em 1Jo 4,8.16. No fundo, então, Deus não revelou para Moisés o seu nome, mas o colocou diante da sua infinita grandeza, sem que, por esta, fosse esmagado, mas carregado de confiança. Esta parece ter sido a interpretação de Jesus dada a Nicodemos (Jo 3,16).
} 
Ex 3,7-15 não se destina a oferecer dados minuciosos do que aconteceu, mas quer comunicar, a um público determinado, o sentido da escolha divina, sem excluir a forma de uma experiência original. Os argumentos usados por Moisés para dissuadir YHWH dos seus desígnios denotam que Moisés se sentiu incapaz diante do "extraordinário da missão"; que ele, apesar de educado entre os sábios do Egito, apresentava "ignorância teológica", sentiu "o temor que não lhe dêem crédito", demonstrou a "sua falta de qualificação", a fim de "terminar apresentando a sua demissão". ${ }^{27}$

Se Moisés titubeou diante da ordem divina ao perguntar: "Quem sou eu para ir ao Faraó e fazer sair do Egito os filhos de Israel?" (v. 11), a resposta enigmática de Deus e o sinal dado a Moisés, que confirmam a sua vocação e missão, convergem para um evento posterior: "servireis a 'Elōhîm nesta montanha" (Ex 3,12; 19,2).

Todavia, a proximidade de Moisés, com YHWH e com o povo, fez dele um mediador ímpar. Por meio dele, YHWH se dirigia ao povo e lhes comunicava os seus desígnios. As palavras de YHWH se tornaram as palavras de Moisés e, por sua vez, as palavras de Moisés se revestiram da autoridade do próprio YHWH, porque ele "escutava-obedecia" a voz de YHWH (Ex 19,9; 33,11; Nm 7,89; Dt 34).

A salvação, vinda da vontade explícita de YHWH, apareceu vinculada a um local específico, o monte Horeb, onde Moisés, por primeiro, experimentou a presença e a vontade libertadora do Deus de teu pai, Deus de Abraão, de Isaac e de Jacó, que tem um nome, YHWH. Isto constitui a base para outros textos (Dt 33,2; Jz 5,4-5; Sl 68,8-11), que mostram YHWH encontrando o seu povo no caminho que conduz à vida: o deserto da existência humana, onde seduz $\mathrm{e}$ lhe fala ao coração (Os 2,16). ${ }^{28}$

\section{Referências bibliográficas}

CHILDS, B. S. El Libro del Éxodo. Comentario crítico y teológico. Estella, Navarra: Editorial Verbo Divino, 2005.

COATS, G. W. Exodus 1-8. Grand Rapids, Michigan / Cambridge, U.K.: William B. Eerdmans Publishing Company, 1999.

${ }^{27}$ SICRE, J. L., Introdução ao Antigo Testamento, p. 104.

${ }^{28}$ ZENGER, E., O Deus da Bíblia, p. 53-56. 
DEIANA, G. Levitico. Milano: Paoline, 2005.

DOZEMAN, T. B. Exodus. Grand Rapids, Michigan / Cambridge, U.K.: William B. Eerdmans Publishing Company, 2009.

ELLIGER, K.; RUDOLPH, W. (Eds.). Biblia Hebraica Stuttgartensia. Editio quinta emendata (opera A. Schenker). Stuttgart: Deutsche Bibelgesellschaft, 1977.

FERNANDES, L. A. Aproximação narrativa a Ex 3,1-6. Revista Caminhando, v. 24, n. 2, p. 57-72, jul./dez. 2019. DOI: https://doi.org/10.15603/2176-3828/caminhando.v24n2p57-72

FERNANDES, L. A. Por que morreremos na tua presença? Uma análise de Gn 47,13-26. Perspectiva Teológica, v. 46, n. 128, p. 113-133, jan./abr. 2014. DOI: https://doi.org/10.20911/21768757v46n128p113/2014

FERRARI, P. L. Il libro dell'Esodo. Padova: Messaggero di Sant'Antonio Editrice, 2012.

FRANCISCO, E. de F. Tetragrama, Teônimos e Nomina Sacra. Os nomes de Deus na Bíblia. Santo André: Kapenke, 2018.

GROSS, F. O Coração do Faraó no livro do Êxodo e da tradição judaica. São Paulo, 2017. 106p. Dissertação. Faculdade de Teologia, Pontifícia Universidade Católica de São Paulo.

HOUTMAN, G. Exodus. Leuven: Peeters, 1993.

MARTIN-ACHARD, R. ענה 'nh II. In: JENNI, E.; WESTERMANN, C. Diccionario Teologico Manual del Antiguo Testamento II. Madrid: Ediciones Cristiandad, 1984. p. 435-447.

PIXLEY, G. V. Êxodo. São Paulo: Paulinas, 1987.

PRIOTTO, M. Esodo. Milano: Paoline, 2014.

RÖMER, T. A Origem de Javé, o Deus de Israel e seu nome. São Paulo: Paulus, 2016.

SACROSANCTUM OECUMENICUM CONCILIUM VATICANUM II. Constitutio Dogmatica de Divina Revelatione Dei verbum (18 nov 1965). Acta Apostolicae Sedis, n. 58, p. 817-836, 1966. 


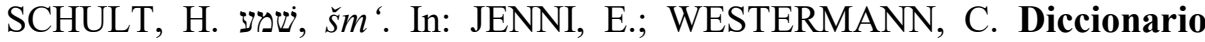
Teologico Manual del Antiguo Testamento II. Madrid: Ediciones Cristiandad, 1984. p. 1221-1232.

SICRE, J. L. Introdução ao Antigo Testamento. Petrópolis/RJ: Vozes, 1995. SKA, J.-L. O Antigo Testamento explicado aos que conhecem pouco ou nada a respeito dele. São Paulo: Paulus, 2015.

ZENGER, E. O Deus da Bíblia. Estudo sobre os inícios da fé em Deus no Antigo Testamento. São Paulo: Paulinas, 1989.

Leonardo Agostini Fernandes

Doutor em Teologia Bíblica pela Pontificia Università Gregoriana Docente de Teologia Bíblica do Departamento de Teologia da

Pontifícia Universidade Católica do Rio de Janeiro Rio de Janeiro / RJ - Brasil E-mail: laf2007@puc-rio.br

Recebido em: 23/08/2021

Aprovado em: 29/10/2021 